\title{
Evaluation of antiviral activity of Ocimum sanctum and Acacia arabica leaves extracts against H9N2 virus using embryonated chicken egg model
}

S. S. Ghoke ${ }^{1,3}$, R. Sood ${ }^{1 *}$ (D, N. Kumar ${ }^{1}$, A. K. Pateriya ${ }^{1}$, S. Bhatia ${ }^{1}$, A. Mishra ${ }^{1}$, R. Dixit ${ }^{1}$, V. K. Singh ${ }^{1}$, D. N. Desai ${ }^{1}$,

D. D. Kulkarni ${ }^{1}$, U. Dimri ${ }^{2}$ and V. P. Singh ${ }^{1}$

\begin{abstract}
Background: In the view of endemic avian influenza H9N2 infection in poultry, its zoonotic potential and emergence of antiviral resistance, two herbal plants, Ocimum sanctum and Acacia arabica, which are easily available throughout various geographical locations in India were taken up to study their antiviral activity against H9N2 virus. We evaluated antiviral efficacy of three different extracts each from leaves of $O$. sanctum (crude extract, terpenoid and polyphenol) and A. arabica (crude extract, flavonoid and polyphenol) against H9N2 virus using in ovo model.

Methods: The antiviral efficacy of different leaves extracts was systematically studied in three experimental protocols viz. virucidal (dose-dependent), therapeutic (time-dependent) and prophylactic (dose-dependent) activity employing in ovo model. The maximum non-toxic concentration of each herbal extracts of $O$. sanctum and A. arabica in the specific pathogen free embryonated chicken eggs was estimated and their antiviral efficacy was determined in terms of reduction in viral titres, measured by Haemagglutination $(\mathrm{HA})$ and real time quantitative reverse transcription polymerase chain reaction (RT-qPCR) assays.

Results: All the extracts of $O$. sanctum (crude extract, terpenoid and polyphenol) and A. arabica (crude extract, flavonoid and polyphenol) showed significant virucidal activity, however, crude extract ${ }_{o c i m u m}$ and terpenoid ocimum $_{\text {, }}$ showed highly significant to significant $(p<0.001-0.01)$ decrease in virus genome copy numbers with lowest dose tested. Similarly, therapeutic effect was observed in all three extracts of $O$. sanctum in comparison to the virus control,

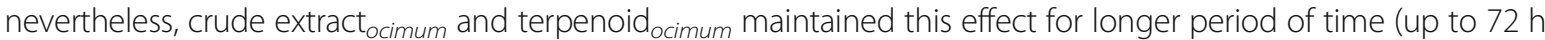
post-incubation). None of the leaves extracts of A. arabica had therapeutic effect at 24 and $48 \mathrm{~h}$ post-incubation,

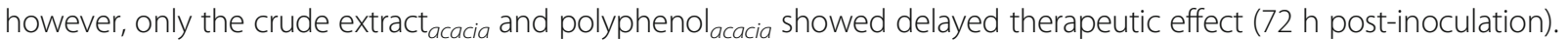
Prophylactic potential was observed in polyphenol acacia with highly significant antiviral activity compared to virus control $(p<0.001)$.
\end{abstract}

Conclusions: The crude extract and terpenoid isolated from the leaves of O. sanctum and polyphenol from A. arabica has shown promising antiviral properties against H9N2 virus. Future investigations are necessary to formulate combinations of these compounds for the broader antiviral activity against H9N2 viruses and evaluate them in chickens.

Keywords: O. sanctum, A. arabica, Avian influenza H9N2, in ovo testing, HA, Real time RT-qPCR

\footnotetext{
* Correspondence: richa.bhatia0609@gmail.com

${ }^{1}$ National Institute of High Security Animal Diseases, Anand Nagar, Bhopal,

Madhya Pradesh, India

Full list of author information is available at the end of the article
}

(c) The Author(s). 2018 Open Access This article is distributed under the terms of the Creative Commons Attribution 4.0 International License (http://creativecommons.org/licenses/by/4.0/) which permits unrestricted use, distribution, and reproduction in any medium, provided you give appropriate credit to the original author(s) and the source, provide a link to the Creative Commons license, and indicate if changes were made. The Creative Commons Public Domain Dedication waiver (http://creativecommons.org/publicdomain/zero/1.0/) applies to the data made available in this article, unless otherwise stated. 


\section{Background}

Influenza A viruses (IAVs), members of the family Orthomyxoviridae are characterized by a single stranded, segmented negative-sense RNA genome. Among the IAVs, avian influenza (AI) H9N2 has become endemic in terrestrial poultry in several countries of the Eurasian continent including India in recent years [1-4]. The spread of AI H9N2 has resulted in significant economic losses in poultry mainly because of reduced egg production and high mortality associated with co-infection with other respiratory pathogens [5]. Although AI H9N2 does not fall under the definition of highly pathogenic avian influenza (HPAI) viruses, there has been ever increasing speculation about pandemic potential of $\mathrm{H} 9 \mathrm{~N} 2$ viruses [6].

So far, a total of 28 laboratory-confirmed cases of human infection with avian influenza A (H9N2) viruses, however none fatal, have been detected globally (http://www.who.int/ influenza/human_animal_interface/Influenza_Summary_ IRA_HA_interface_25_02_2016.pdf). Among them, the recent one includes from China [7]. In addition, serological evidences of AI H9N2 virus exposure to human have been reported on several occasions from Iran, China and India [8-11]. The higher human infection capability of these viruses was provided by the fact that H9N2 binds to $\alpha-2,6$ sialic acid receptors that are abundant in the human upper respiratory tract while $\mathrm{H} 5 \mathrm{~N} 1$ chiefly bind to human receptors in the lower respiratory tract [12]. The recently emerged influenza A (H7N9) and (H10N8) infecting humans had acquired gene segments from H9N2 virus $[13,14]$. The potential of genetic reassortment of IAVs, due to segmented genome, from different animal species is thought to be a mechanism for the emergence of influenza viruses with pandemic potential [14]. Endemicity of H9N2 circulation in poultry especially in India could further aggravate the current situation. Among the control measures, existing vaccines are unable to keep up with the mutation rates of viruses. New vaccine development takes a long time and at the same time, viruses are also developing resistance to the currently used drugs [15]. Hence, there is no immediate response drug to the newly emerging virus infections/outbreaks. To address this problem, there is an exigent need for the development of a new paradigm preventive and therapeutic agent to control the immediate spread of viral outbreaks. In this scenario, traditional herbal medicines have been postulated to prove effective due to fewer side effects, relatively low cost and easy availability [16].

Two plants, Ocimum sanctum and Acacia arabica are widely distributed and easily available throughout various geographical locations in India. The efficacy of $O$. sanctum as inhibitory compound has been documented against several viruses like Newcastle Disease virus, Vaccinia virus and Infectious Bursal Disease virus [17]. Similarly, A. arabica has been explored for its virucidal properties against Peste des petits ruminants (PPR) virus [18], along with inhibition of Goatpox virus replication [19]. However, antiviral H9N2 influenza activity of different extracts derived from the leaves of these two plants has not been studied.

For evaluation of the antiviral properties of medicinal plants against IAVs, three methods viz. tissue culture [20, 21], laboratory/experimental animals [22] and in ovo model [23] have been used frequently. Each method has its pros and cons. We preferred in ovo model, which is at the borderline of in vitro and in vivo studies and thus does not conflict with either ethical or legal aspects of animal protection $[23,24]$. Therefore, keeping in view the endemicity and pandemic potential of H9N2, this study was taken up to assess the H9N2 inhibitory potential of various extracts derived from leaves of $O$. sanctum and $A$. arabica using in ovo model.

\section{Methods}

\section{Virus and embryonated chicken eggs}

Avian Influenza virus, A/chicken/CL/15-12/103075 (H9N2) was collected from one of the major water body of Maharashtra state of India during an ongoing surveillance programme. Specific pathogen free (SPF) embryonated chicken eggs (ECEs) were obtained from SPF Unit of ICAR- National Institute of High Security Animal Diseases, Bhopal, India. This virus was passaged two times in the allantoic fluid of 10-days-old SPF ECEs to make seed virus stock. The virus seed stock was titrated by the haemagglutination test as per OIE protocol [25]. The allantoic cavities of 10-day-old SPF ECEs were inoculated with $0.2 \mathrm{ml}$ of seed virus suspension (1:100 diluted in $0.01 \mathrm{M}$ phosphate-buffered saline, $\mathrm{pH} 7.2$ ) and incubated for $72 \mathrm{~h}$ at $37{ }^{\circ} \mathrm{C}$ followed by chilling at $4{ }^{\circ} \mathrm{C}$ overnight. The allantoic fluid was harvested, clarified by centrifugation and then stored at $-80{ }^{\circ} \mathrm{C}$. The ten-fold serially diluted virus was inoculated in the allantoic cavity of SPF ECEs and the virus titer was estimated as the egg infective dose $50 \%$ per $\mathrm{ml}\left(\mathrm{EID}_{50} / \mathrm{ml}\right)$.

\section{Plant extracts and antiviral drugs}

Two plants, O. sanctum (commonly known as Tulsi) and A. arabica (commonly known as Babul), native to the Indian subcontinent were used in this study. The leaves of these plants were collected from Madhya Pradesh, India and identified by Dr. S.S. Ghoke through standard morphological and anatomical techniques. Plants were authenticated and voucher numbers for O. sanctum (Specimen\#: vi p-1050313) and A. arabica (Specimen\#: vi p-174629) were obtained. Crude extracts of these two plant leaves were prepared in hydro-methanol (1:1 dilution with water) by standard hot continuous extraction method using Soxhlet apparatus [26]. Two class compounds each in identified plants, O. sanctum (terpenoid 
and polyphenol) and A. arabica (flavonoid and polyphenol) were isolated and purified by ultraviolet-visible prep HPLC technique [27]. Antiviral drugs, Amantadine hydrochloride (Sigma, USA) and Oseltamivir (FLUVIR, Hetero Drugs Ltd., India), the currently approved drugs for influenza [28] were used as drug control and hydro-methanol as vehicle control group.

\section{Toxicity assay of plant extracts and antiviral drugs}

To determine the maximum non-toxic concentration (MNTC) of all the extracts of O. sanctum (crude extract $_{\text {ocimum, }}$ terpenoid ocimum, $_{\text {, polyphenol }}$ ocimum $_{\text {) }}$ and A. arabica (crude extract acacia $_{\text {, flavonoid }}$ acacia and polyphenol acacia ), the guidelines prescribed by the Organization for Economic Co-operation and Development (OECD) were followed [29]. Average egg biomass of 10 SPF ECEs which included the embryo along with its allantoic sac and yolk was measured and the maximum dose for each of the herbal extract groups that could be used without inducing toxicity to the embryo was calculated as $135 \mathrm{mg} / \mathrm{kg}$ of egg biomass [29]. Afterwards, the MNTC was again assessed in the in ovo model. $0.1 \mathrm{ml}$ of two-fold dilution of each of the plant extracts (200, 175, 150, 135, $100,75,50,25,10$ and $5 \mathrm{mg} / 0.1 \mathrm{ml}$, diluted in extraction medium hydro-methanol) were inoculated into the allantoic cavity of 10-days-old SPF ECEs in triplicates. The SPF ECEs inoculated with $0.1 \mathrm{ml}$ of hydro-methanol alone served as vehicle control. The MNTCs of amantadine and oseltamivir antiviral drugs were determined by inoculating 5.33, 8 and $16 \mu \mathrm{g} / 0.1 \mathrm{ml}$ and $1.75,2.66$ and $5.25 \mu \mathrm{g} /$ $0.1 \mathrm{ml}$, respectively into the allantoic cavity of 10-days-old SPF ECEs separately in triplicates. All the inoculated SPF ECEs were incubated at $37{ }^{\circ} \mathrm{C}$ till hatching and were candled twice daily for checking the viability.

\section{Assessment of efficacy of herbal extracts against H9N2 virus using in ovo model}

The antiviral activity of each plant crude extract and its isolated class compounds were assessed in three different formats viz; virucidal (dose-dependent), therapeutic (time-dependent) and prophylactic (dose-dependent).

\section{Dose-dependent virucidal activity}

A total of nine treatment groups (each treatment group with five 10-days-old SPF ECEs) were made for the determination of virucidal activity of herbal extracts against A/chicken/CL/15-12/103075 (H9N2). Of the nine, six treatment groups corresponded to the respective six herbal extracts (crude extract ocimum, terpenoids $_{\text {ocimum, }}$, polyphenol $_{\text {ocimum; }}$ crude extract $_{\text {acacia }}$, flavonoid ${ }_{\text {acacia }}$, polyphenol $_{\text {acacia }}$ ) used in this study. The remaining three treatment groups were the drug control, the vehicle control and the virus control group. $0.1 \mathrm{ml}$ of two-fold dilution of pre-calculated MNTC (135 mg, $67 \mathrm{mg}$, and $33 \mathrm{mg}$ ) of different plant leaves extracts (three extracts each from two different plants leaves) was incubated with $500 \mathrm{EID}_{50} /$ $0.1 \mathrm{ml}$ of $\mathrm{H} 9 \mathrm{~N} 2$ virus separately at $37^{\circ} \mathrm{C}$ for $2 \mathrm{~h}$. The drug control group included amantadine hydrochloride (MNTC-16 $\mu \mathrm{g} / 0.1 \mathrm{ml}$ ) incubated with $500 \mathrm{EID}_{50} / 0.1 \mathrm{ml}$ of $\mathrm{H} 9 \mathrm{~N} 2$ virus and the virus control group included 500 $\mathrm{EID}_{50} / 0.1 \mathrm{ml}$ of $\mathrm{H} 9 \mathrm{~N} 2$ virus incubated with $0.1 \mathrm{ml} \mathrm{PBS}$ for $2 \mathrm{~h}$ at $37{ }^{\circ} \mathrm{C}$. The vehicle control group comprised of $0.1 \mathrm{ml}$ of hydro-methanol incubated with $500 \mathrm{EID}_{50} /$ $0.1 \mathrm{ml}$ of $\mathrm{H} 9 \mathrm{~N} 2$ virus. Afterwards, $0.1 \mathrm{ml}$ of each of the virus-extract mixture was inoculated into the allantoic cavity of 10-day-old SPF ECEs (5 each) separately and incubated at $37{ }^{\circ} \mathrm{C}$ for $72 \mathrm{~h}$. The allantoic fluid was harvested from each of the treatment groups $72 \mathrm{~h}$ post-incubation. The presence of virus in the allantoic fluid was assessed by haemagglutination (HA) test as per methods described [30] and quantified by real time RT-qPCR [31] (Fig. 1).

\section{Therapeutic, time-dependent activity}

Eight treatments groups (except the vehicle control group) as formulated for testing of virucidal antiviral activity were made for testing the therapeutic efficacy in a time dependent manner. In each of the treatment groups, $500 \mathrm{EID}_{50} / 0.1 \mathrm{ml}$ of $\mathrm{H} 9 \mathrm{~N} 2$ virus was inoculated into the allantoic cavity of 10-day-old SPF ECEs (6 eggs for each group) and incubated at $37{ }^{\circ} \mathrm{C}$ for $2 \mathrm{~h}$. Then, the MNTC dose $(135 \mathrm{mg} / 0.1 \mathrm{ml})$ of each plant extract was injected into the sharp pole of albumen of these ECEs separately and incubated at $37{ }^{\circ} \mathrm{C}$. This route has been suggested as an improved model for testing antiviral drugs especially if the bioavailability of the drug is poor [32]. In the drug control group, oseltamivir (MNTC-2.66 $\mu \mathrm{g} / 0.1 \mathrm{ml}$ ) was injected through albumen route $2 \mathrm{~h}$ post-virus inoculation. The allantoic fluid was harvested from each of the treatment group at 24, 48 and $72 \mathrm{~h}$ post-inoculation (Fig. 1). The presence of virus in the allantoic fluid was tested by HA test and quantified by real time RT-qPCR.

\section{Prophylactic, dose-dependent activity}

For testing of prophylactic efficacy, same eight treatment groups as mentioned in above testing methodologies were used to examine the effect of extracts in a dose dependent manner. In each of the treatment groups, the two-fold dilution of MNTC (135 mg; $67 \mathrm{mg} ; 33 \mathrm{mg} /$ $0.1 \mathrm{ml}$ ) of different plant extracts (three extracts each from two plants leaves) was inoculated into the allantoic cavity of 10-day-old SPF ECEs (5 eggs for each group) and incubated at $37{ }^{\circ} \mathrm{C}$ for $2 \mathrm{~h}$. Then, $500 \mathrm{EID}_{50} / 0.1 \mathrm{ml}$ of $\mathrm{H} 9 \mathrm{~N} 2$ virus was inoculated into the allantoic cavity of each of these eggs and incubated at $37{ }^{\circ} \mathrm{C}$ for $72 \mathrm{~h}$ (Fig. 1). In the drug control group, amantadine hydrochloride (MNTC-16 $\mu \mathrm{g} / 0.1 \mathrm{ml}$ ) was given through 
Virucidal (dose dependent) Protocol

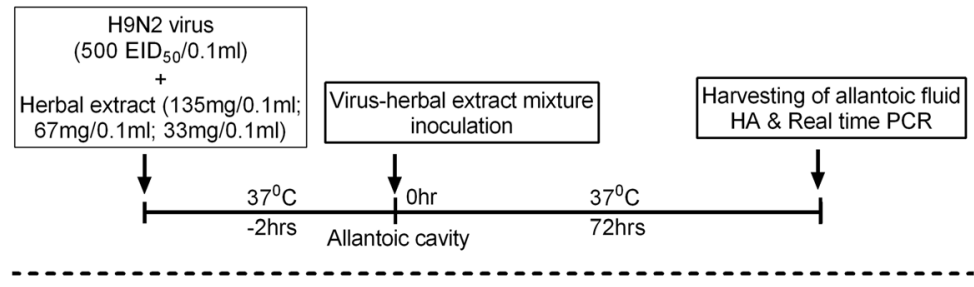

Therapeutic (time dependent ) Protocol
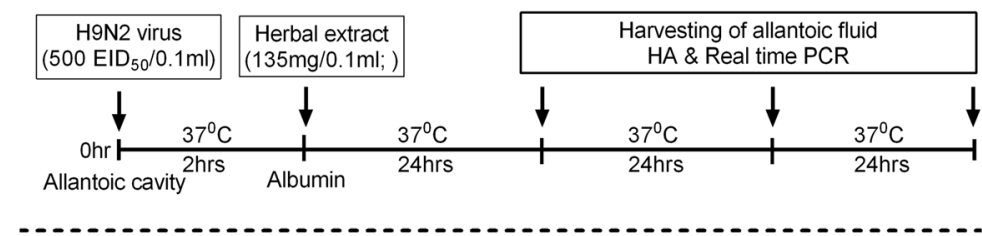

Prophylactic (dose dependent) Protocol

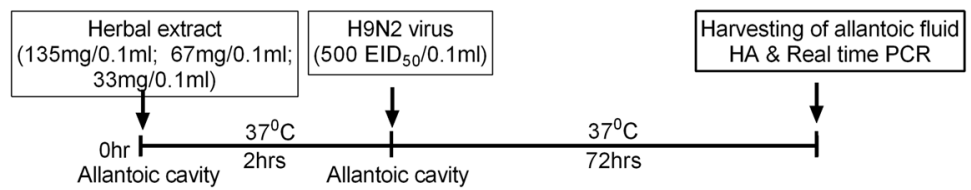

Fig. 1 Experimental protocols for the assessment of the antiviral activity of Ocimum sanctum and Acacia arabica leave extracts against H9N2 virus using in ovo model

allantoic cavity $2 \mathrm{~h}$ post-virus inoculation. The presence of virus in the allantoic fluid was detected by HA test and quantified by real time RT-qPCR.

\section{Real-time quantitative reverse transcription PCR}

Viral RNA from the respective allantoic fluids was extracted using QIAamp Viral RNA mini kit (Qiagen, Germany) as per the recommendations of the manufacturer. One step RT-qPCR was carried out in duplicates as per standard method [31]. The PCR assay was conducted on Light Cycle 480 Real-Time PCR, Roche, USA. The fluorescence reading was noted at the end of each extension step. No template control and no probe control were included in each run.

\section{Statistical analysis}

The infectivity titer of the H9N2 virus (A/chicken/CL/ $15-12 / 103075)$ was expressed as $\mathrm{EID}_{50} / \mathrm{ml}$ and was calculated as per the standard method [33]. The data is presented as mean \pm standard deviation. For the analysis of the significance of differences among the different treatment groups in terms of the virus genome copy number, two ways analysis of variance (ANOVA) with Tukey post hoc test was used. $P$ values equal to or less than 0.05 were considered statistically significant. Analyses were performed using GraphPad Prism version 6.0 (GraphPad Software, SanDiego, CA, USA).

\section{Results}

Toxicity assay of plant extracts and antiviral drugs

In a first set of experiments, MNTC was calculated for each herbal extracts and antiviral drugs in the SPF ECEs. The criterion of non-toxicity of herbal extracts was identified as the absence of death of embryos up to hatching of all the eggs (three per drug concentration) at various concentrations $(200,175,150,135,100,75,50,25,10$ and $5 \mathrm{mg} / 0.1 \mathrm{ml})$. Irrespective of the different herbal extracts, all the ECEs that had received $200 \mathrm{mg} / 0.1 \mathrm{ml}$ of extract died within $48 \mathrm{~h}$ of post-inoculation. The mortality of $50-15 \%$ was observed in ECEs given 175 and $150 \mathrm{mg} / 0.1 \mathrm{ml}$ extract, while those that received $135 \mathrm{mg} / 0.1 \mathrm{ml}$ or less showed no evidence of mortality till hatching. The concentrations of antiviral drugs tested were non-toxic to the embryos at the dose of $16 \mu \mathrm{g} /$ $0.1 \mathrm{ml}$ and $2.66 \mu \mathrm{g} / 0.1 \mathrm{ml}$ for amantadine hydrochloride and oseltamivir, respectively and thus have been used as MNTC throughout the study.

\section{Antiviral activity on the basis of haemagglutination test}

The aim of this experiment was to identify the most effective extract in inhibiting the H9N2 virus replication in the SPF ECEs. The virus challenge dose was identified on the basis that there was no mortality in the eggs up to $72 \mathrm{~h}$, in any of the virus challenge groups made, for evaluating the antiviral activities for different doses as well as time intervals. 


\section{Dose-dependent virucidal activity}

All the herbal extracts treatment groups including drug control did not show any HA titer irrespective of decreasing dose $(135,67,33 \mathrm{mg} / 0.1 \mathrm{ml})$ treatments, indicating that even the low dose of all extracts were effective in inhibiting the replication of H9N2 virus. Allantoic fluid collected from these treatment groups were given two consecutive passages in SPF eggs to ascertain the absence of H9N2 replication which did not show any HA titer and reconfirmed the virucidal activity. However on further two-fold reduction in dose to $17.5 \mathrm{mg} / 0.1 \mathrm{ml}$ for each extract, we found that crude extract $_{\text {ocimum, }}$ terpenoid ocimum $_{\text {, crude }}$ extract $_{\text {acacia }}$ and flavonoid $_{\text {acacia }}$ treatment groups showed a mean HA titer of $2^{4.2}, 2^{5}, 2^{4.2}$ and $2^{5.3}$, respectively which on further two fold reduction of dose to $8.75 \mathrm{mg} / 0.1 \mathrm{ml}$ remained almost same as above indicating loss of virucidal activity at lower doses. However, polyphenol ${ }_{\text {ocimum }}$, polyphenol $_{\text {acacia }}$ and the drug control amantadine treatment groups did not show any HA titer even at the lowest dose $(8.75 \mathrm{mg} / 0.1 \mathrm{ml})$ tested indicating a high virucidal activity of these class compounds (Fig. 2).

\section{Time-dependent therapeutic activity}

Among the extracts of O. sanctum, only crude extract ${ }_{\text {ocimum }}$ treatment group showed absence of HA titer in the allantoic fluid harvested at all the three time intervals $(24,48$ and $72 \mathrm{~h}$ ) post-inoculation. The drug control group oseltamivir also showed absence of HA titer indicating no viral replication. The other two extract treatment groups, terpenoid $_{\text {ocimum }}$ and polyphenol ocimum, $_{\text {, however had mean }}$ HA titers $2^{4.8}$ and $2^{3.8}$, respectively at $72 \mathrm{~h}$ post-inoculation (Fig. 2).

\section{Dose-dependent prophylactic activity}

All the three extracts of $O$. sanctum at doses 135 and $67 \mathrm{mg} / 0.1 \mathrm{ml}$ showed prophylactic potential as revealed by the absence of HA titers. However, on further reduction of dose to $33 \mathrm{mg} / 0.1 \mathrm{ml}$, all the three extracts (crude extract $_{\text {ocimum }}$, terpenoid ocimum $_{\text {aim }}$ and polyphenol $_{\text {ocimum }}$ ) showed a mean HA titer of $2^{5.9}, 2^{5.6}$ and $2^{3.6}$ respectively. In the case of $A$. arabica, MNTC dose $(135 \mathrm{mg} / 0.1 \mathrm{ml})$ of all the three extracts showed absence of HA titer. Lower doses $(67$ and $33 \mathrm{mg} / 0.1 \mathrm{ml})$ of any of the extracts of $A$. arabica were not effective in preventing viral replication. The drug control group showed complete absence of HA titer (Fig. 2).

\section{Antiviral activity on the basis of viral quantification by real time RT-qPCR \\ Virucidal, dose-dependent activity}

The aim of this experiment was to quantify the viral amount and identify the most effective extract in inhibiting the H9N2 virus replication. The crude extract $_{\text {ocimum }}$ when administered at the dose of $135 \mathrm{mg} /$ $0.1 \mathrm{ml}$ significantly inhibited the virus replication compared to virus control group $(p<0.001)$. At the same dose $(135 \mathrm{mg} / 0.1 \mathrm{ml})$, the other four extracts; terpenoid ${ }_{\text {ocimum }}$, polyphenol $_{\text {ocimum }}$, flavonoid acacia $_{\text {and }}$ and

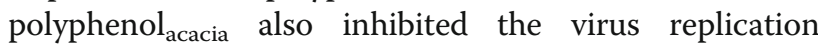
significantly $(p<0.05-0.01)$ (Fig. 3$)$. On reducing the dose $(67 \mathrm{mg} / 0.1 \mathrm{ml})$, only crude extract $_{\text {ocimum }}$ and terpenoid $_{\text {ocimum }}$ were effective $(p<0.05)$. Further reducing the dose $(33 \mathrm{mg} / 0.1 \mathrm{ml})$, crude extract $_{\text {ocimum }}$ remained effective $(p<0.05)$ (Fig. 3). Non-significant efficacy was recorded within both groups of herbal extracts of $O$. sanctum and A. arabica in the present study.

Therapeutic, time-dependent activity All the three extracts of O. sanctum (crude extract ocimum $_{\text {, }}$ terpenoid ocimum $_{\text {sim }}$ and polyphenol ocimum $_{\text {) }}$ were significantly effective in limiting the H9N2 virus replication in the SPF ECEs at different time intervals (24, 48 and $72 \mathrm{~h}$ post-inoculation) $(p<0.001-0.0001)$. Within the O. sanctum treatment group, crude extract ${ }_{\text {ocimum }}$ was found to have significantly high efficacy in comparison to terpenoid ocimum $(p<0.05)$ and polyphenol ${ }_{\text {ocimum }}(p<0.01)$ at $48 \mathrm{~h}$ post-inoculation as indicated by decrease in viral genome copy numbers (Fig. 4). However, terpenoid ocimum $_{\text {showed significantly }}$ high inhibitory activity compared to crude extract ${ }_{\text {ocimum }}$ $(p<0.0001)$ and polyphenol ocimum $(p<0.001)$ at $72 \mathrm{~h}$ post-inoculation.

In the case of A. Arabica, none of the extracts were effective initially at 24 and $48 \mathrm{~h}$ post-inoculation $(p>0.05)$, however, at $72 \mathrm{~h}$ post-inoculation, crude extract ${ }_{\text {acacia }}$ $(p<0.001)$ and polyphenol ${ }_{\text {acacia }}(p<0.01)$ depicted therapeutic activity as indicated by significant decrease in the virus genome copy numbers as compared to virus control group (Fig. 4). However, differences in the time dependent therapeutic effect among the extracts of $A$. arabica were non-significant $(p>0.05)$. On comparison of antiviral treatment between the two groups it was found that all three extracts of $O$. sanctum treatment group had significantly higher $(p<0.05-0.0001)$ antiviral efficacy than the crude extract $_{\text {acasia }}$ or polyphenol acacia $_{\text {extracts. }}$.

Prophylactic, dose-dependent activity The prophylactic potential of all the herbal extracts were determined against H9N2 virus in the SPF ECEs. In the O. sanctum group, only crude extract ocimum $_{\text {and }}$ polyphenol ocimum $_{\text {cim }}$ treated ECEs showed significant $(p<0.05)$ decrease in viral genome copy numbers at dose of $135 \mathrm{mg} / 0.1 \mathrm{ml}$ (Fig. 5). The decrease in viral genome copy numbers was non-significant at lower doses of 67 and $33 \mathrm{mg} / 0.1 \mathrm{ml}$ in all the three extracts of $O$. sanctum groups. In A. arabica group, only polyphenol acacia $_{\text {as }}$ wore successful in reducing the viral genome copy numbers at doses of 135 

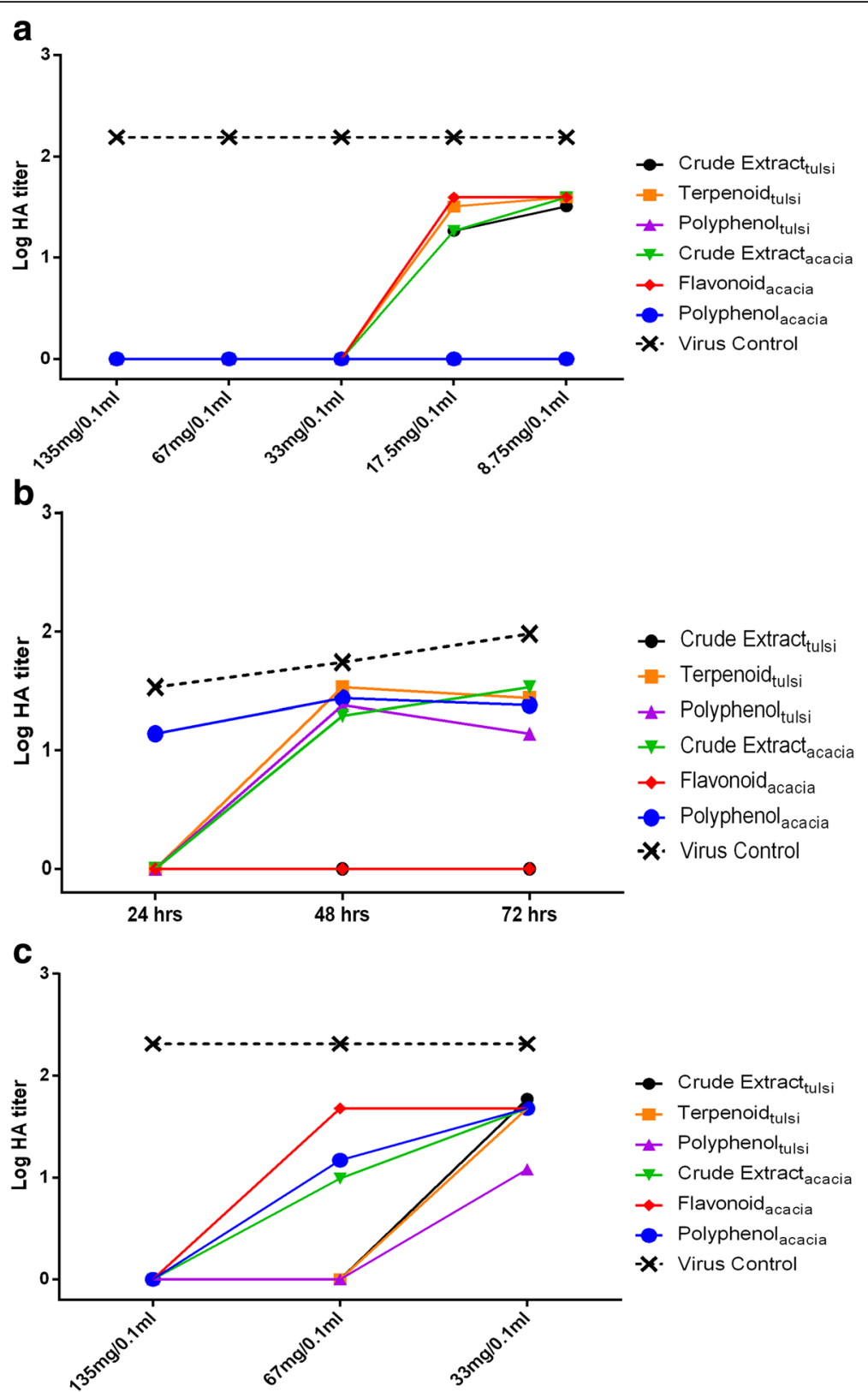

Fig. 2 Measurement of antiviral activity of $O$. sanctum and A. arabica leave extracts against H9N2 virus using HA assay. a Dose-dependent virucidal activity; b Time-dependent therapeutic activity; c Dose-dependent prophylactic activity. The virus control group included 500 EID $50 / 0.1 \mathrm{ml}$ of H9N2 virus incubated with $0.1 \mathrm{ml} \mathrm{PBS}$ for $2 \mathrm{~h}$ at $37^{\circ} \mathrm{C}$. The HA titer were expressed as log HA titer

$(p<0.0001)$ and $67 \mathrm{mg} / 0.1 \mathrm{ml}(p<0.001)$ while it became ineffective at low dose of $33 \mathrm{mg} / 0.1 \mathrm{ml}(p>0.05)$ (Fig. 5). The other two extracts of $A$. arabica, crude extract $_{\text {acacia }}$ and flavonoid ${ }_{\text {acacia }}$ were not effective as prophylactic extract at any of the doses $(p>0.05)$.

\section{Discussion}

Spread of H9N2 subtype has demonstrated an increased theoretical threat to humans because of the potential emergence of novel subtypes of avian influenza [13]. It is being considered as an emerging pandemic threat in view of the clinical and confirmed cases of H9N2 in China, Hong Kong, Bangladesh and Egypt [14]. This reaffirms the need for search of new compounds with antiviral activity. With increase in drug resistance to synthetic antivirals, natural products remain an important alternative for the control infectious diseases. In the present study, the in ovo model has been used for studying antiviral activities of different leaves extracts of Ocimum sanctum and Acacia arabica against low pathogenic avian influenza (LPAI) H9N2. 


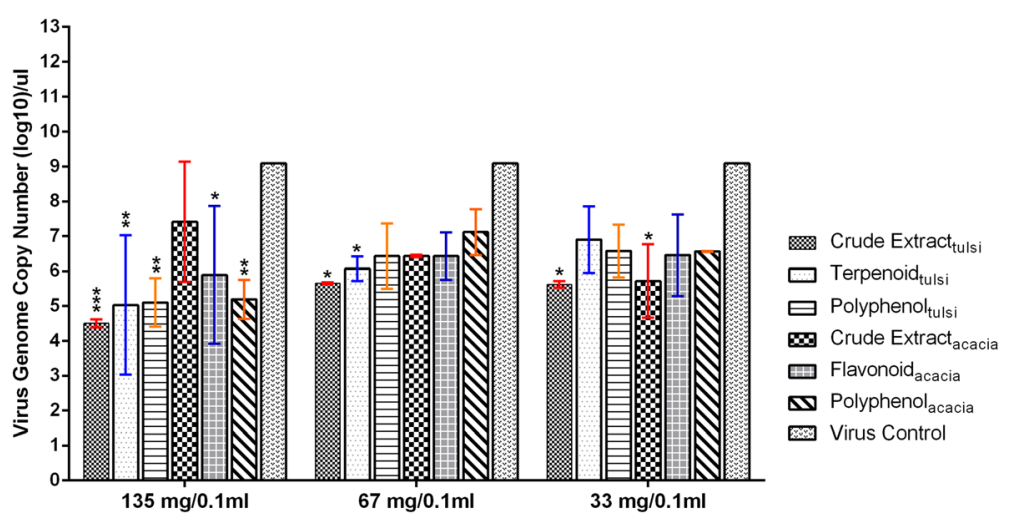

Fig. 3 Assessment of virucidal activity of the $O$. sanctum and A. arabica leaves extracts in a dose-dependent manner by Real Time RT-qPCR assay. Each error bar represents standard deviation (SD) from the 5 ECEs. The virus control group included $500 \mathrm{EID}_{50} / 0.1 \mathrm{ml}$ of H9N2 virus. Statistical significance was assessed by two ways analysis of variance (ANOVA) with Tukey post-hoc test $\left({ }^{*} p<0.05,{ }^{* *} p<0.01,{ }^{* * *} p<0.001,{ }^{* * * *} p<0.0001\right.$ )

In our previous work we were able to demonstrate $100 \%$ virucidal activity of cold aqueous extract of bark of A. arabica at a concentration of $0.625 \mathrm{mg} / \mathrm{ml}$ against HPAI H5N1 using in vitro model. Mild therapeutic activity was also demonstrated up to $48 \mathrm{~h}$ in cold aqueous extract of Ocimum tenuiflorum when tested against HPAI H5N1 [20].

In the present work, we had selected two plants, Ocimum sanctum and Acacia arabica for studying their efficacy against avian influenza H9N2 virus because these plants are widely distributed and easily available throughout various geographical locations in India and have strong record in the literature for their antiviral activity against different viruses [16, 17]. Three different approaches viz. virucidal (dose dependent), therapeutic (time dependent) and prophylactic (dose dependent) were employed to systematically explore the potential of extracts of leaves of $O$. sanctum (crude extract, terpenoid and polyphenol) and A. arabica (crude extract, flavonoid and polyphenol) against LPAI H9N2 using in ovo model.

In dose dependent virucidal activity, all the extracts of both the plants in doses $(135,67$ and $33 \mathrm{mg} / 0.1 \mathrm{ml})$ displayed absence of HA titer indicating that all the extracts had inhibitory potential. On further reduction of dose rate in double dilution, polyphenol ${ }_{\text {acasia }}$ and polyphenol Ocimum only maintained virucidal activity up to a low dose rate of $8.75 \mathrm{mg} / 0.1 \mathrm{ml}$ which was confirmed by absence of HA in the harvested allantoic fluid of ECEs in the next two passages also. This virucidal effect could be due to masking/blocking of HA protein of the virus by the herbal extracts during the incubation period, which might have inhibited the H9N2 virus replication. Catechin compounds in polyphenols are known to have antiviral activity mediated by preventing adsorption of viruses to cells [34, 35]. Highly significant to significant decrease in the viral genome copy numbers was recorded in all the extracts at the MNTC dose $(135 \mathrm{mg} / 0.1 \mathrm{ml})$

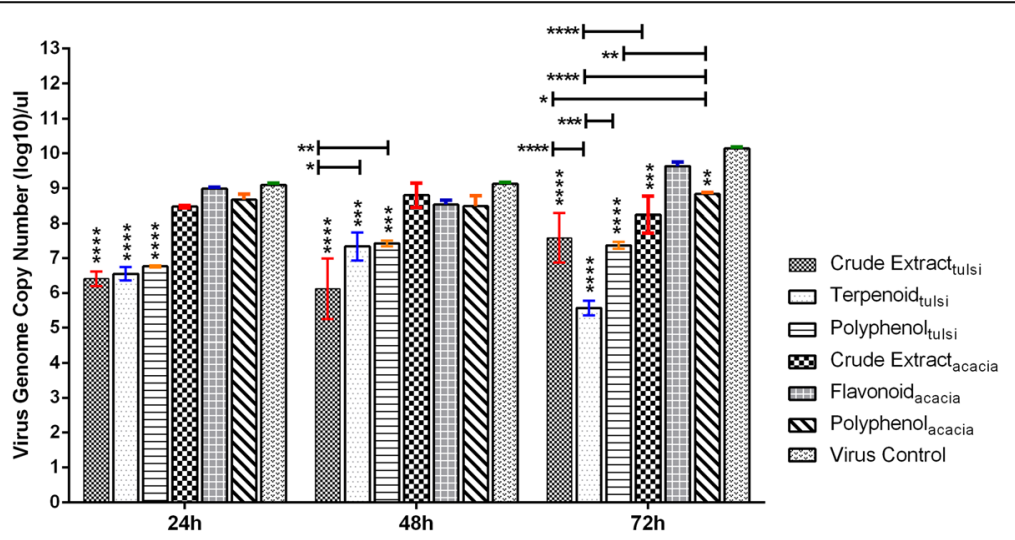

Fig. 4 Assessment of therapeutic activity of the $O$. sanctum and A. arabica leaves extracts in a time-dependent manner by Real Time RT-qPCR assay. Each error bar represents standard deviation (SD) from the 6 ECEs. The virus control group included $500 \mathrm{EID}_{50} / 0.1 \mathrm{ml}$ of H9N2 virus. Statistical significance was assessed by two ways analysis of variance (ANOVA) with Tukey post-hoc test $\left({ }^{*} p<0.05,{ }^{* *} p<0.01,{ }^{* * *} p<0.001,{ }^{* * * *} p<0.0001\right.$ ) 


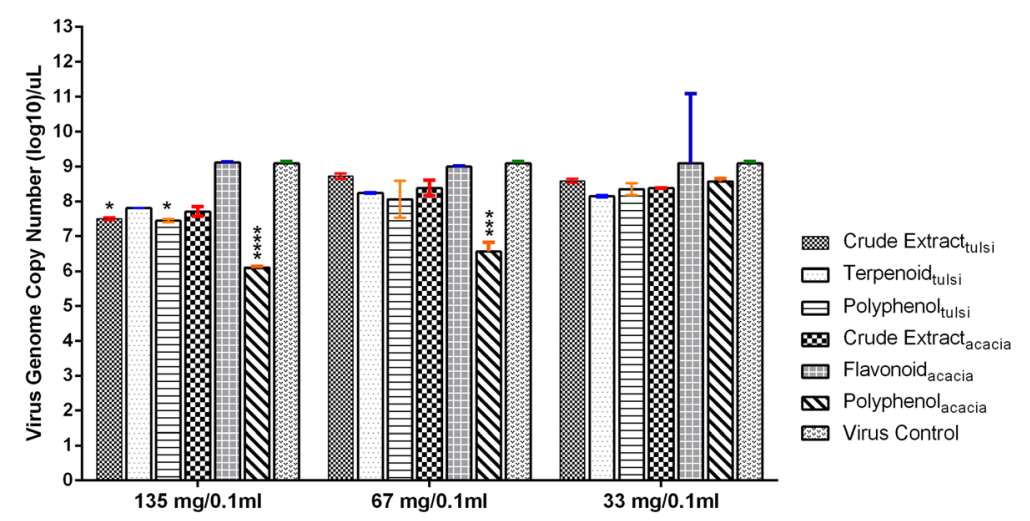

Fig. 5 Assessment of prophylactic activity of the $O$. sanctum and A. arabica leaves extracts in a dose-dependent manner by Real Time RT-qPCR assay. Each error bar represents standard deviation (SD) from the 5 ECEs. The virus control group included $500 \mathrm{EID}_{50} / 0.1 \mathrm{ml}$ of H9N2 virus. Statistical significance was assessed by two ways analysis of variance (ANOVA) with Tukey post-hoc test $\left({ }^{*} p<0.05,{ }^{* *} p<0.01,{ }^{* * *} p<0.001,{ }^{* * *} p<0.0001\right)$

except crude extract ${ }_{\text {acacia }}(P<0.05-0.001)$. Although the virucidal effect was seen more prominently in the HA test where the virus HA titer was absent in comparison to the virus control (mean HA titer $2^{7.3}$ ) and vehicle control (mean HA titer $2^{5.8}$ ), the quantification of the virus by real time RT-qPCR also corroborated with the HA results especially at higher extract doses. The results of both the assays clearly indicated that crude extract ${ }_{\text {ocimum }}$ in particular is a potent inhibitor of $\mathrm{H} 9 \mathrm{~N} 2$ virus replication.

Our study is further supported by the fact that individual plant extracts were less effective compared to crude extracts which may due to synergistic effect of individual component and some of the uncharacterised components [36]. Earlier studies for evaluation of virucidal activity against $\mathrm{H} 9 \mathrm{~N} 2$ virus by crude extract chinecea $_{\text {and }}$

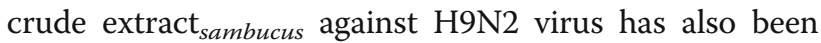
ascribed to blocking of the influenza virus entry via at least two virion targets, $\mathrm{HA}$ and NA on the surface of virus [37]. Mentofin (combination of eucalyptus oil and peppermint) in another study has been reported to have complete virucidal activity against $\mathrm{H} 9 \mathrm{~N} 2$ virus in the presence of organic matter (skimmed milk) [38].

On assessing the therapeutic potential, we were able to demonstrate that all the extracts of $O$. sanctum (crude extract $_{\text {ocimum }}$, terpenoid ocimum $_{\text {and }}$ polyphenol ocimum $_{\text {) sig- }}$ nificantly reduced the viral genome copy numbers $(P<0.0001)$ at all the tested time intervals of 24,48 and $72 \mathrm{~h}$ post-inoculation. However, crude extract ocimum $_{\text {and }}$ and terpenoid $_{\text {ocimum }}$ had higher therapeutic potential at 48 and $72 \mathrm{~h}$ post-inoculation, respectively. Although terpenoid $_{\text {oсimum }}$ and polyphenol ${ }_{\text {ocimum }}$ treated groups showed a mean HA titer of $2^{5.1}, 2^{4.8}$, respectively at $48 \mathrm{~h}$ post-inoculation and a slightly decreased mean HA titer of $2^{4.8}, 2^{3.8}$, respectively at $72 \mathrm{~h}$ post-inoculation, the genome copy numbers in these treated groups were significantly reduced in comparison to virus control $(P<0.0001)$. The possible reason for this could be due to the decrease in concentration of the active ingredient which might have allowed the virus to replicate because of single dose regimen followed in the experiment. In addition, other possible reason might be the high sensitivity of real time PCR assay. Surprisingly, in A. arabica treated groups, crude extract ${ }_{\text {acacia }}$ and polyphenol $_{\text {acacia }}$ showed significant decrease in viral genome copy numbers at a later time interval of $72 \mathrm{~h}$ post-inoculation $(P<0.01)$. Since the route of administration was via albumen, slow movement/distribution of A. arabica extracts from albumen to allantoic cavity might be the reason for delayed effect. Variable bioavailability of drugs, oseltamivir and ribavirin via albumin route has been established previously also [39].

In the case of dose dependent prophylactic activity assessment, only the high doses of crude extract ${ }_{\text {ocimum }}$, polyphenol $_{\text {ocimum }}$ and polyphenol ${ }_{\text {acacia }}$ were effective as observed by the absence of HA titer and significant decrease in viral genome copy numbers. Lower doses of these extracts failed to provide sufficient prophylactic activity. Activity of different polyphenolic compounds in plants worked their best when added to the cells just around or before the time of virus adsorption using in vitro model. They do possess high binding affinities with viral HA and NA which might be a reason for their prophylactic activity [34, 40-42]. Thus, the therapeutic or prophylactic efficacy testing using in ovo model could be improved by considering the multiple dose regimens and monitoring the active ingredients diffusion of plant extracts through suitable methods. Moreover, since these extracts shows no adverse effect, a clinical pilot study would give further information on the potency of these extracts in protecting against $\mathrm{H} 9 \mathrm{~N} 2$ virus infection in chickens.

\section{Conclusions}

The treatment with the crude extract derived from the leaves of Ocimum sanctum leads to the significant H9N2 
virus reduction in assessing the all the three; virucidal, therapeutic and prophylactic activities using in ovo model. At this stage, we conclude that crude extract ${ }_{\text {ocimum }}$ could be a promising extract for developing safe and efficacious antiviral compound against $\mathrm{H} 9 \mathrm{~N} 2$ virus. The protective efficacy of crude extract ocimum $_{\text {might be attributed }}$ to multiple mechanisms of action, e.g. specific inhibition of a stage in viral intracellular multiplication and non-specific interference with virus-cell interactions like masking/blocking the HA glycoprotein. Furthermore, terpenoid ${ }_{\text {ocimum }}$ was also effective for virucidal and therapeutic activity and polyphenol $l_{\text {acacia }}$ for prophylactic activity. Nevertheless, it would of great importance to study further which particular active ingredient or a combination of these three compounds (crude extract ocimum $_{\text {, }}$ terpenoid ocimum $_{\text {and }}$ polyphenol ${ }_{\text {acacia }}$ ) could provide broader antiviral activity against H9N2 virus. This study also established the use of influenza virus-infected chick embryos for evaluation of new antiviral substances which could reduce the use of small laboratory animals required for such studies.

\section{Abbreviations}

ECE: Embryonated chicken egg; EID 50 : Egg infectious dose 50\%; HA: Haemagglutination; HI: Haemagglutination inhibition; HPAl: Highly pathogenic avian influenza; LPAI: Low pathogenic avian influenza; MNTC: Maximum non-toxic concentration; OECD: Organization for Economic Co-operation and Development; PBS: Phosphate buffer saline;

RT-qPCR: Quantitative reverse transcription polymerase chain reaction; SPF: Specific pathogen free

\section{Acknowledgements \\ The authors are thankful to the Director, NIHSAD and Director, IVRI for providing the necessary infrastructure for carrying out the research work.}

\section{Funding}

The Indian Council of Agricultural Research, India provided the necessary funding for the research. The funders had no role in study design, data collection and analysis, decision to publish, or preparation of the manuscript.

\section{Availability of data and materials}

The datasets for supporting the outcomes of the study are included in the article. However, additional information can be provided on request made to the corresponding author.

\section{Authors' contributions}

RS and SSG designed the research theme. SSG, RS and AKP designed the methods and performed the experiments. RS and NK performed the statistical analyses, interpretation of the data and draft the manuscript. AM, $R D, V K S, D N D$ did the supporting work for the experimentation. SB, DDK, UD, VPS revised the paper critically for important intellectual contents. All authors have read and approved the manuscript.

\section{Ethics approval and consent to participate}

Not applicable

\section{Competing interests}

The authors declare that they have no competing interests.

\section{Publisher's Note}

Springer Nature remains neutral with regard to jurisdictional claims in published maps and institutional affiliations.

\section{Author details}

${ }^{1}$ National Institute of High Security Animal Diseases, Anand Nagar, Bhopal, Madhya Pradesh, India. Indian Veterinary Research Institute, Izatnagar, Bareilly, Uttar Pradesh, India. ${ }^{3}$ Present Address: Department of Veterinary Epidemiology and Preventive Medicine, COVAS, Udgir, Latur, Maharashtra, India.

Received: 9 November 2017 Accepted: 23 May 2018

Published online: 05 June 2018

\section{References}

1. Lee DH, Song CS. H9N2 avian influenza virus in Korea: evolution and vaccination. Clin Exp Vaccine Res. 2013;2:26-33.

2. Shanmuganatham K, Feeroz MM, Jones-Engel L. Antigenic and molecular characterization of avian influenza A (H9N2) viruses, Bangladesh. Emerg Infect Dis. 2013;19(9):1393-402.

3. Nagarajan S, Rajukumar K, Tosh C, Ramaswamy V, Purohit K, Saxena G, Behera P, Pattnaik B, Pradhan HK, Dubey SC. Isolation and pathotyping of H9N2 avian influenza viruses in Indian poultry. Vet Microbiol. 2009;133:154-63.

4. Pawar SD, Kale SD, Rawankar AS. Avian influenza surveillance reveals presence of low pathogenic avian influenza viruses in poultry during 2009-2011 in the West Bengal state, India. Virol J. 2012;9:151-7.

5. Jakhesara SK, Bhatt VD, Patel NV. Isolation and characterization of H9N2 influenza virus isolates from poultry respiratory disease outbreak. Springerplus. 2014;3:196.

6. Paul AE. Is H9N2 avian influenza virus a pandemic potential? Can J Infect Dis Med Microbiol. 2008;20:e35-6.

7. Huang $Y$, Li X, Zhang H. Human infection with an avian influenza A (H9N2) virus in the middle region of China. J Med Virol. 2015;10:1641-8.

8. Heidari A, Mancin M, Nili H. Serological evidence of H9N2 avian influenza virus exposure among poultry workers from Fars province of Iran. Virol J. 2016;13:16.

9. Wang Q, Ju L, Liu P. Serological and virological surveillance of avian influenza A virus H9N2 subtype in human and poultry in Shanghai, China, between 2008 and 2010. Zoonoses Public Health. 2015;62:131-40.

10. Zhou M, Liu Q, Sun Q. Full genome sequence of a natural reassortant H9N2 avian influenza virus isolated from domestic ducks in Jiangsu Province. China Genome Announc. 2014;1:e00463-13.

11. Pawar SD, Tandale BV, Raut CG. Avian influenza H9N2 sero-prevalence among poultry workers in Pune, India. PLoS One. 2012;7(5):e36374.

12. Shelton $\mathrm{H}$, Roberts $\mathrm{KL}$, Molesti E. Mutation in haemagglutinin that affect receptor binding and $\mathrm{pH}$ stability increase replication of a PR8 influenza virus with $\mathrm{H} 5 \mathrm{HA}$ in the upper respiratory tract of ferrets and may contribute to transmissibility. J Gen Virol. 2013;94(Pt 6):1220-9.

13. Chen $Y$, Liang $W$, Yang S. Human infections with the emerging avian influenza A H7N9 virus from wet market poultry: clinical analysis and characterization of viral genome. Lancet. 2013;381(9881):1916-25.

14. Liu D, Shi W, Gao GF. Poultry carrying H9N2 acts as incubators for novel human avian influenza viruses. Lancet. 2014:383(9920):869.

15. Howard CR, Fletcher NF. Emerging virus diseases: can we ever expect the unexpected? Emerg Microbes Infect. 2012;1:e46.

16. Dhar LM, Dhar MM, Dhawan BN, Ray C. Screening of Indian plants for biological activity. Part I Indian J Exp Biol. 1968;6:232-47.

17. Gupta N, Charan P. Therapeutic uses of Ocimum sanctum Linn. (Tulsi) with a note on eugenol and its pharmacological actions: a short review. Indian J Physiol Pharmacol. 2005;49:125-31.

18. Balamurugan V, Sen A, Saravanan P. Potential effect of Acacia Arabica on Peste des petits ruminants virus replication. Pharm Biol. 2008:46:171-9.

19. Bhanuprakash V, Hoshamani M, Balamurugan V. In vitro antiviral activity of plant extracts on goat pox virus replication. Indian J Exp Biol. 2008;46:120-7.

20. Sood R, Bhatia S, Bhatnagar H. Phytochemical analysis and in-vitro screening of selected Indian medicinal plants for antiviral activity against highly pathogenic avian influenza virus. Spatula DD. 2013;3(3):81-8.

21. Serkedjieva J, Velcheva M. In vitro anti-influenza virus activity of the pavine alkaloid (-)-thalimonine isolated from Thalictrum simplex L. Antivir Chem Chemother. 2003;14:75-80.

22. Shimizu T, Hino A, Tsutsumi A. Anti-influenza virus activity of propolis in vitro and its efficacy against influenza infection in mice. Antivir Chem Chemother. 2008;19:7-14.

23. Shin WJ, Lee KH, Park MH, Seong BL. Broad-spectrum antiviral effect of Agrimonia pilosa extract on influenza viruses. Microbiol Immunol. 2010; 54: 11-19. 
24. Bolls M, Ridel RJ, Worden AN. Animals and alternatives in toxicity testing. London: Academic Press; 1983.

25. OIE. Avian Influenza. In: OIE Terrestrial Manual; 2015.

26. Sood R, Swarup D, Bhatia S, Kulkarni DD, Dey S, Saini M, Dubey SC. Antiviral activity of crude extracts of Eugenia jambolana Lam. against highly pathogenic avian influenza (H5N1) virus. Indian J Exp Biology. 2012;50:179-86,

27. Gerber F, Krummen M, Potgeter H, Roth A, Siffrin C, Spoendlin C. Practical aspects of fast reversed-phase high-performance liquid chromatography using $3 \mu \mathrm{m}$ particle packed columns and monolithic columns in pharmaceutical development and production working under current good manufacturing practice. J Chromatogr A. 2004;1036(2):127-33.

28. Hedlund M, Larson JL, Fang F. Antiviral strategies for pandemic and seasonal influenza. Viruses. 2010;2:1766-81.

29. OECD 2001. OECD guidelines for testing of chemicals. http://www.oecd.org/ chemicalsafety/risk-assessment/1948370.pdf. Accessed 1 May 2017.

30. Song JM, Park KD, Lee KH, Byuna YH, Park JH, Kimb SH, Kimc JH, Seong BL. Biological evaluation of anti-influenza viral activity of semisynthetic catechin derivatives. Antivir Res. 2007;76:178-85.

31. Payungporn S, Chutinimitkul S, Chaisingh A. Single step multiplex real-time RT-PCR for H5N1 influenza A virus detection. J Virol Methods. 2006;131 (2):143-7.

32. Wang JX, Zhou JY, Yang QW, Chen Y, Li X, Piao YA, Li HY. An improved embryonated chicken egg model for the evaluation of antiviral drugs against influenza A virus. J Virol Methods. 2008;153:218-22.

33. Reed $\mathrm{L}$, Muench $\mathrm{H}$. A simple method of estimating fifty percent endpoints. Am J Epidemiol. 1938;27:493-7.

34. Song JM, Lee KH, Seong BL. Antiviral effect of catechins in green tea on influenza virus. Antivir Res. 2005;68:66-74.

35. Nakayama M, Suzuki K, Toda M. Inhibition of the infectivity of influenza virus by tea polyphenols. Antivir Res. 1993;21:289-99.

36. Hudson JB. The use of herbal extracts in the control of influenza. J Med Plants Res. 2009;3(13):1189-95.

37. Karimi S, Ali M, Dadras H. The effect of Echinacea purpurea and Sambucus nigra L. on H9N2 avian influenza virus in infected chicken embryo. Veterinarski Archiv. 2014;84(2):153-65.

38. Barbour EK, Yaghi RH, Jaber LS. Safety and antiviral activity of essential oil against avian influenza and Newcastle disease viruses. Intern J Appl Res Vet Med. 2010;8(1):60-4

39. Tare DS, Pawar SD. Use of embryonated chicken egg as a model to study the susceptibility of avian influenza H9N2 viruses to oseltamivir carboxylate. J Virol Methods. 2015;224:67-72.

40. Imanishi N, Tuji Y, Katada Y. Additional inhibitory effect of tea extract on the growth of influenza A and B viruses in MDCK cells. Microbiol Immunol. 2002:46:491-4.

41. Sokeman M, Angelova M, Krumova E. In vitro antioxidant activity of polyphenol extracts with antiviral properties from Geranium sanguineum L. Life Sci. 2005;76:2981-93.

42. Ehrhardt C, Hrincius ER, Korte V. A polyphenol rich plant extract, CYSTUS052, exerts anti-influenza virus activity in cell culture without toxic side effects or the tendency to induce viral resistance. Antivir Res. 2007;76:38-47.

\section{Ready to submit your research? Choose BMC and benefit from:}

- fast, convenient online submission

- thorough peer review by experienced researchers in your field

- rapid publication on acceptance

- support for research data, including large and complex data types

- gold Open Access which fosters wider collaboration and increased citations - maximum visibility for your research: over $100 \mathrm{M}$ website views per year

At BMC, research is always in progress.

Learn more biomedcentral.com/submissions 